\title{
The impact of psychological contracts on employee engagement at a university of technology
}

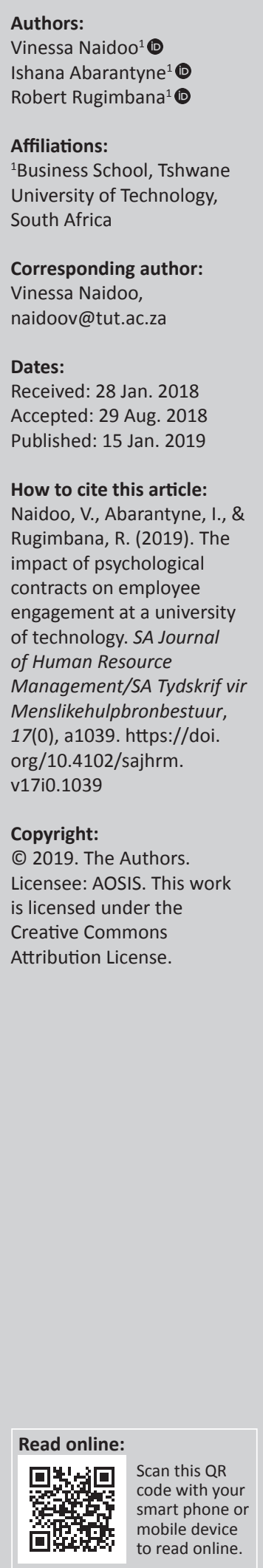

Orientation: Changing organisational dynamics have caused a need for organisations to understand the employment relationship processes and outcomes in order to improve organisational effectiveness, increase productivity and retain talented employees.

Research purpose: The purpose of the study is to determine which elements of the academic employee's psychological contract are impacting employee engagement at a university of technology.

Motivation for the study: The study was motivated by the findings of a 2013 climate survey at an institute of higher education, indicating that many employees were dissatisfied and believed that their expectations were not met by the organisation.

Research approach/design and method: A quantitative technique via online questionnaires was employed for data collection. The sample size was 400 out of 900 academic staff members.

Main findings: The study confirmed that most employees appear to have developed a positive psychological contract. It indicated, however, that many employees may be experiencing discord in the employment relationship. Both transactional and relational elements of the psychological contract appeared to be essential to academic employees.

Practical/managerial implications: The study identified factors of importance to academic employees that should be considered in the compilation of retention policies.

Contribution/value-add: The results of the study could contribute towards addressing some of the challenges by creating a better understanding of the needs of academic employees and the impact of psychological contract fulfilment and breach. This could benefit the higher education sector as a whole.

\section{Introduction}

For an organisation to achieve its strategic objectives and obtain a competitive advantage, it must be committed to appointing, developing, sustaining and retaining the right people with the appropriate skills (Devi, 2009, p. 3). South African institutions of higher education face the challenge that a significant number of academics will retire in the near future. The knowledge of these academics and specialist employees is viewed as a very important source of wealth in which competitive advantage lies (Gupta, Aggarwal, Samaria, Sarda, \& Bucha, 2012, p. 737). These knowledge workers have a high degree of expertise, education and experience and their primary purpose involves the creation, distribution and application of knowledge (Davenport, 2005, p. 10). Should institutions be unable to obtain, develop and retain such talented employees, they will be unable to produce high-quality graduates to contribute towards the economy nor fulfil their objective of expanding their institutions (Badat, 2010, pp. 5-45). To do so certain expectations of the employee need to be met by the employer.

These expectations of the employee form an unwritten contract referred to as a 'psychological contract' (Aggarwal \& Bhargava, 2009, p. 238). The concept of the psychological contract is a framework applied as a means of understanding and managing employment relations (Conway \& Briner, 2002, p. 287). When the employee perceives a breach in this contract, hope and trust are lost, levels of engagement plummet and the employee is more likely to consider leaving the organisation (Rayton \& Yalabik, 2014, p. 2386). A climate survey conducted at an institute of higher education in Pretoria during 2013 indicated that many employees were dissatisfied, believed that their trust had been betrayed and that their expectations were not being met by the organisation. By implication the employees may perceive a breach in their psychological contract with the organisation. The possibility of the organisation losing valuable employees was largely 
the motivation for this study. When understanding the impact of the psychological contract on staff retention better, the organisation might be able to fulfil employees' expectations to a larger extent and thus prevent the loss of these employees.

The main objective was therefore to determine the impact of the psychological contract on employee engagement at an institute of higher education. In order to reach the objective, the research question was stated as follows:

- What elements of the academic employee's psychological contract have impacted academic employee engagement at an institute of higher education in Pretoria, Gauteng?

Because limited studies have been conducted on the nature of the relationship between psychological contracts and employee engagement (Bruce, Zeynep, \& Yalabik, 2014, p. 2384), particularly in the higher education sector, this study will add greatly to the body of academic knowledge. The study focused mainly on the use of the psychological contract as a tool towards improving levels of employee engagement and retention at a university of technology in Pretoria, Gauteng.

\section{Literature review}

\section{Brief overview of psychological contracts}

Barnard's theory of equilibrium of 1938 referred to an employment relationship as an exchange, suggesting that an employee's continued participation in an organisation depended on adequate rewards received from the employer (Coyle-Shapiro \& Parzafall, 2008, p. 24). The term 'psychological contract' was first used by Argyris in the early 1960s. This contract focuses explicitly on employees' perceptions of the employment deal (Höglund, 2012, p. 127). At the basis of the psychological contract is social exchange theory, based on the principal of reciprocity. Reciprocity implies that an individual feels obliged to reciprocate when receiving a benefit (Sonnenberg, Koene, \& Paauwe, 2011, p. 666).

\section{Development of the psychological contract}

While the terms of an employment contract are formal and legally binding, psychological contracts are informal, subjective in nature, not legally binding and lacking in clarity. Coyle-Shapiro (2002, p. 930) maintains that the formation of the psychological contract begins even before an individual starts at a new job and then goes through various stages of development. This process continues over more or less the first year of employment and includes perceptions of the fulfilment or the violation of promised obligations. Once formed, psychological contracts are quite stable and resistant to change (Tomprou \& Nikolaou, 2011, p. 358).

\section{Factors influencing the development of psychological contracts}

Aggarwal and Bhargava (2009, p. 11) illustrate the role of some of the factors influencing employees' promissory expectations by citing previous studies. Table 1 presents a summary of their findings.
TABLE 1: Factors influencing the development of psychological contracts.

\begin{tabular}{|c|c|}
\hline Study & Findings \\
\hline $\begin{array}{l}\text { Freese and } \\
\text { Schalk (1996) }\end{array}$ & $\begin{array}{l}\text { The study found more male employees were dissatisfied with } \\
\text { opportunities for personal development. }\end{array}$ \\
\hline Singh (1998) & $\begin{array}{l}\text { Singh's study revealed that an individual's past experiences } \\
\text { influence their attitudes and behaviour at work. This could } \\
\text { motivate employees to focus on their own goals rather than those } \\
\text { of the organisation. }\end{array}$ \\
\hline $\begin{array}{l}\text { Martin, Staines } \\
\text { and Pate (1998) }\end{array}$ & $\begin{array}{l}\text { White-collar workers had different expectations and training } \\
\text { needs than blue-collar workers. While blue-collar workers' training } \\
\text { needs were linked with a desire to remain with the organisation, } \\
\text { white-collar workers saw training as a means of improving their } \\
\text { marketability outside the organisation. }\end{array}$ \\
\hline $\begin{array}{l}\text { Blancero, } \\
\text { DelCampo and } \\
\text { Marron (2007) }\end{array}$ & $\begin{array}{l}\text { A study conducted on the Hispanic population of the USA } \\
\text { indicated a significant difference in perceived fairness because of } \\
\text { age. }\end{array}$ \\
\hline $\begin{array}{l}\text { Winter and } \\
\text { Jackson (2006) }\end{array}$ & $\begin{array}{l}\text { This study on the role of hierarchical levels on the psychological } \\
\text { contract affirms that, although managers and employees had } \\
\text { similar responses to the state of the psychological contract, they } \\
\text { ascribed different reasons to these states. Managers had rational } \\
\text { explanations and emphasised restrictions in resources as a cause. } \\
\text { Employees had emotional explanations and attributed it to unfair, } \\
\text { uncaring and distant managers. }\end{array}$ \\
\hline
\end{tabular}

Source: Aggarwal, U., \& Bhargava, S. (2009). Reviewing the relationship between human resource practices and psychological contract and their impact on employee attitude and behaviours: A conceptual model. Journal of European Industrial Training, 33(1), 11. https:// doi.org/10.1108/03090590910924351

\section{Types of psychological contracts}

Psychological contracts are categorised in terms of two underlying dimensions, transactional and relational. Transactional contracts refer to a narrow range of behaviours over a limited time period, emphasising financial rewards in exchange for a fairly tightly defined set of employee behaviours. Relational contracts, on the other hand, are based on a longerterm relationship where a broader range of benefits and opportunities are provided in exchange for a deeper and more extensive commitment to the organisation. These contracts tend to be more unstructured, uncertain and open-ended and to rely on a higher level of trust (Coyle-Shapiro \& Parzefall, 2008, p. 13; Middlemiss, 2011, p. 33). A considerable overlap has been identified, with aspects such as pay being present in both.

\section{Content of the psychological contract}

The content of a psychological contract is important because it establishes the deal between employee and organisation. Guest and Conway (1998) indicated that the content of the psychological contract consists of trust, fairness and the delivery of the deal.

Trust can be defined as a willingness to be vulnerable to the actions of another party (Mayer, Davis, \& Schoorman, 1995, p. 712). It is closely interlinked with mutual obligations and is built over a certain period, creating an exchange relationship. Middlemiss (2011, p. 42) suggested that trust is present in all psychological contracts and underpins transactional as well as relational obligations.

Cohen (2013, p. 606) emphasises the role of fairness perceptions in shaping employee attitudes, particularly organisational commitment. Managers and other organisational agents must be sensitive to employees' perceptions about how they are treated, to ensure that perceptions of unfairness do not damage the employment relationship.

Fair treatment of employees not only fosters trust but also influences outcomes such as employee engagement. 
Organisations should therefore be transparent and have regular communication with employees. Supervisors should be well trained with good interpersonal skills and should treat their subordinates with respect (Aggarwal, 2014, p. 61).

The deal refers to the obligations included in the psychological contract. These include job content, job security, training and development, rewards and benefits, fair pay, good working conditions and future career prospects (Atkinson \& Cuthbert, 2006, p. 649). In a study of academic psychological contracts, Shen (2010, p. 584) found that the most desirable obligation for academics was the provision of a safe workplace. Other academicspecific items include providing funding and time off for research, which are additional to the constructs of the general psychological contract.

\section{Relationship between the psychological contract and turnover intentions}

Because the psychological contract is based on the norm of reciprocity, it can be inferred that an employee will reciprocate fulfilled promises with loyalty and lower turnover intentions. Literature on turnover intention indicates employee attitudes such as organisational commitment and job satisfaction to be the main causes of turnover intention. The higher the level of job satisfaction and organisational commitment an employee experiences, the lower the turnover intentions.

One of the reasons that organisational efforts to limit turnover intentions do not always deliver the expected results is because human resources managers do not focus on the inducements that are important to employees when they develop retention policies. They devote much time to the financial inducements in their retention policies, but they should shift their focus to factors that employees deem important, such as social atmosphere and job content, rather than focusing only on extrinsic factors such as work-life balance and financial rewards. They should consider what their employees value and how they evaluate the organisation's efforts towards retention management if they are to contribute in a cost-efficient way to the strategic objectives of the organisation (De Vos \& Meganck, 2008, p. 56, 58). In other words, they should consider the psychological contract rather than the actual contract alone.

George $(2015$, p. 114, 116) found that turnover intention factors for professional workers at the organisational level, such as management style, pleasant working experience, adequate resources, a degree of flexibility, being part of a team, opportunity to learn new skills or for advancement, are important. At the job level, a degree of autonomy, flexibility in workload decisions, transparent and fair pay decisions, opportunity for employees to craft their jobs and suitable work-life balance are important. These factors that were found to be important in the retention of professional employees are also commonly mentioned in relation to psychological contract breach, suggesting that a relationship exists between turnover intentions and psychological contract breach.

\section{Academic contract fulfilment}

Management in the higher education sector may find that the concept of a psychological contract offers a powerful means of organisational leverage in pursuit of employee retention and higher levels of employee organisational commitment. Shen (2010, p. 584) found that the overall level of academic psychological contract fulfilment is low with the least fulfilled contents of the psychological contract being fair promotion, consultation, recognition of contributions, providing funding for research and pay equity. The most fulfilled elements are the provision of adequate training, reasonable workload, the provision of resources to do work and the provision of adequate time for research.

\section{The effects of psychological contract fulfilment or breach}

Bal, De Cooman and Mol (2013, p. 110) found that psychological contract fulfilment results in an increase in work engagement, positive attitude towards the job and lower turnover intentions. Employees become more motivated to invest in their work and contribute more to the organisation, indicating higher levels of employee engagement (Rayton \& Yalabik, 2014, p. 4). In addition, psychological contract fulfilment could also act as a buffer against the negative effects of various job demands such as highly stressful conditions, thereby contributing positively to employee health and wellbeing (Parzefall \& Hakanen, 2010, p. 5).

Contract breach, on the other hand, refers to the event where either party fails to fulfil the perceived obligations. This leads to the erosion of trust and a breakdown in the employment relationship. Parzefall and Coyle-Shapiro (2011, p. 13) emphasise the role of cognitive processes on perceptions of breach and their outcomes. Factors such as trust, perceived organisational support and support from supervisors and mentors may help in mitigating the negative outcomes of psychological contract breach. They also state that the effect will be more severe when perceived as intentional rather than caused by environmental factors or an honest misunderstanding.

\section{Responses to psychological contract breach}

Empirical evidence (Cassar, 2001; Hui, Lee, \& Rousseau, 2004; Pate, Martin, \& McGoldrick, 2003) suggests that psychological contract breach is associated with and impacts negatively on a wide range of employee attitudes and behaviours such as psychological contract violation, intentions to leave the organisation, reduced trust in the organisation, employee motivation, in-role job performance, organisational citizenship behaviour, employee engagement, intentions to quit, turnover, increased cynicism, lower job satisfaction, organisational commitment and poor mental health outcomes (Deery, Iverson, \& Walsh, 2006, p. 169; Flower, Demir, McWilliams, \& Johnson, 2015, p. 107).

\section{Employee retention}

According to De Vos and Meganck (2008, p. 45), employee retention refers to the ability of an organisation to retain its employees. It can be defined as the ability to hold onto those 
employees an organisation wants to keep for longer than the competitors.

Allen, Bryant and Vardaman (2010, p. 60) suggest that effective retention management requires ongoing diagnosis of the nature and causes of turnover. It requires a strategic approach to determine the largest impact of retention on organisational success and the development of an appropriately targeted and organised bundle of retention initiatives. Talent cannot easily be imitated and can be a valuable strategic tool in the pursuit of a successful organisation. There are several negative implications when critical talent leaves to take up positions with a competitor. These include:

- the loss of knowledge and expertise

- the likelihood of critical information falling into a competitor's hands

- the need for considerable investment to hire and train replacements.

Despite the efforts of human resource managers, employee turnover is often prevalent. It results in a drain on management time and creates pressures in workforce planning and service delivery. Intangible costs include the negative impact on culture and employee morale, adverse effects on social capital and the erosion of organisational memory. The average turnover costs for a full-time professional employee in the private sector have been estimated to be as high as $150 \%$ of the employee's annual compensation package (Pitts, Marvel, \& Fernandez, 2011, p. 751). Pitts et al. (2011, p. 752) cluster the factors usually associated with turnover into three categories, namely demographic factors, workplace satisfaction factors and organisational or relational factors.

\section{Retention of professional workers}

Professional workers are a group of people who are involved in the same kind of work and belong to a specific profession. They often display high levels of expertise, autonomy, a belief in the regulation of the profession by its members and a belief in the importance of the specific profession. Professional workers are loyal to and identify with both the profession and their organisation (George, 2015, p. 102, 103).

\section{Employee engagement}

According to Devi (2009, p. 3), engaged employees help organisations to perform better. Engagement in this regard refers to the level that an employee's heart and mind is being captured by an organisation (Kaye \& Jordan-Evans, 2003, p. 11). It can be characterised by energy, involvement and positive interaction in the workplace and is regarded as an important concept for enhancing staff recruitment and retention.

\section{Definition of engagement}

Academic literature provides a number of definitions for employee engagement. Kahn (1990, p. 694) defines it as the 'harnessing of organizational members' selves to their work roles'. Engagement is a multidimensional construct where an employee can be emotionally, cognitively or physically engaged. The more employees are engaged in each dimension, the higher the overall level of personal engagement.

Emotional engagement: This entails connecting in a meaningful way with co-workers and managers. When employees feel that their opinions count and that their managers are interested in their development, they respond positively to their managers, contributing to managerial and organisational effectiveness.

Cognitive engagement: It speaks of an employee who is acutely aware of their mission and role in the work environment. When employees understand their purpose in the organisation and are given opportunities to grow and excel and constantly attempt to progress, they are more likely to be successful. Therefore, employees who are able to connect with others in the work environment, who know what is expected of them and who experience meaning in their work, are engaged (Luthans \& Peterson, 2002, p. 378).

Schaufelli (2002), as quoted by Parzefall and Hakanen (2010, p. 6), defines conceptualised engagement as consisting of three components, namely vigour, dedication, and absorption. These are explained below:

- Vigour refers to a high level of positive energy at work, resilience and willingness to invest one's efforts even in the face of difficulties.

- Dedication refers to being strongly involved in one's work and includes feelings of inspiration, a sense of significance and enthusiasm about one's work.

- Absorption is characterised by being fully concentrated and happily engrossed in one's work, whereby time passes quickly and it becomes difficult to detach from work (p. 6).

\section{Levels of engagement}

Overall engagement levels internationally are not very high. Many economies worldwide pay the price for active disengagement. Empirical evidence (Gallup, 2013), reveals that less than $36 \%$ of employees worldwide are engaged. The rest are either not engaged, neutral or actively disengaged (Bhattacharya, 2015, p. 299; Gallup, 2013, p. 17). The Gallup survey $(2013$, p. 29, 56, 59) found that South Africa has one of the highest percentages of actively disengaged employees in the world, with only $9 \%$ engaged, $46 \%$ not engaged and $45 \%$ actively disengaged. Gallup (2013) explains:

- Not engaged or neutral: Employees who are not engaged are not hostile or disruptive but are merely unconcerned with important organisational activities.

- Actively disengaged: These employees are on a mission to damage an organisation. They have a higher rate of absenteeism and are more likely to quit than engaged employees.

- Engaged employees: This group of employees is involved in, enthusiastic about and psychologically 
committed to their jobs. They help to build an organisation and are in an emotional and psychological state that goes beyond having a merely satisfactory experience at work to one of $100 \%$ psychological commitment to their roles (p. 19).

\section{Benefits of engagement}

Chughtai and Buckley (2013, p. 397) suggest that engagement is a vital source of competitive advantage, particularly in knowledge-intensive organisations. Engaged employees are most likely to drive innovation, growth and revenue, build new products and services, generate new ideas and ultimately help spur the economy. Because of their strong emotional connection to their organisation, they are willing to go the extra mile. Engagement contributes to meaningful business outcomes such as productivity, profitability, customer satisfaction, organisational citizenship behaviour and superior performance (Gallup, 2013, p. 29).

Based on the knowledge gained from the literature review and in support of the main research question, this study set out to answer the following subquestions:

- What are academic employees' perceptions of the outcomes of psychological contract fulfilment or breach?

- What is the current state of the academic employees' psychological contract?

- What transactional or relational elements of the psychological contract are important to academic employees?

- What are the factors that influence discontent in the employment relationship?

- What are academic employees' perceptions of the current retention practices at their organisation?

The article will proceed in explaining the methodology of the study as well as the results obtained from the data. It will also present recommendations to institutes of higher educations as well as for future research.

\section{Research design}

This research falls under a positivistic paradigm with emphasis on a deductive approach. The study predominantly relied on quantitative data and the employment of a survey questionnaire, which is aligned with the characteristics of positivistic research (Neuman, 2006).

\section{Methods of this study}

The study was conducted in the social world using the quantitative research paradigm. The research is both descriptive and analytical in nature and data were collected through a standard questionnaire. A survey questionnaire was deemed the most appropriate method for this study, allowing insight into the motivations, beliefs and attitudes of the respondents. It offers a greater possibility of anonymity, is better for sensitive and personal topics and is cost-effective. It also provides an overview of a representative sample of a large population and allows easy comparison with other studies that use similar questions (Punnett \& Shenkar, 2004, p. 136).

\section{Population and sample}

The target population for this study comprised permanent and fixed-term academic employees across all six faculties of a university of technology in Pretoria, Gauteng. Academics from the lowest level (junior lecturer) to the highest level (professor) were targeted in view of the practical implications, specifically the significant costs associated with the loss of talented employees in the higher education sector. The population measured 800 permanent and 100 fixed-term academic employees.

A total stratified random sample of 300 academic employees was chosen for the study. A sample from each faculty was selected in proportion to the size of the faculty in relation to the population as a whole. A pilot test was performed by 30 academic employees who were contacted personally. The indication was that the questionnaire was in a suitable format and the questions clear and easy to understand, although somewhat lengthy.

\section{Data collection}

Primary as well as secondary data were collected for this study. The main sources of secondary data were various journals, Internet articles, research articles and textbooks. Primary data were collected via a self-administered questionnaire. The link to the online questionnaire was distributed on 22 September 2016 with a 4-month response window. The response rate was fairly slow because of student protest action that took place nationally at higher education institutions during that period. A reasonable sample of 230 responses was received, representing a response rate of $57.5 \%$. A total of 23 responses were incomplete; therefore only 207 responses were included in the study.

\section{Data management}

Because participation in this study was online and the data were presented in Excel spreadsheets, it did not have to be manually encoded, captured or cleaned, eliminating errors. A range of descriptive and inferential data analysis techniques were conducted on the primary data collected in order to address the research question.

The research results were presented as graphical and descriptive statistics. Bar graphs, frequency tables and percentages were calculated using Stata version 13 statistical software. The mean, standard deviation median, minimum and maximum values were produced for categorical variables.

The chi-square test was used to test for association between any two categorical variables. The interpretation was performed at $a=0.05$. Thus, the association was declared 
significant if the $p$-value was found to be less than 0.05 . The chi-square was found appropriate in determining the significance of the relationship between categorical variables of the sample. Pearson's $R$ was used, where the level of measurement of both variables presumes the properties of interval-level (numerical) data.

To analyse data from the open-ended questions, quantitative content analysis was used to extract common themes through frequency counts. The textual information was reduced and its properties, such as the frequencies of most used keywords, were systematically identified, in the content of the openended questions.

\section{Results}

\section{The questionnaire}

Standardised questionnaires on psychological contracts were adapted in order to include items that were deemed relevant to the higher education sector. The questionnaire consisted of three sections with the 'Introduction' section addressing the demographic information of the respondents. The 'Research design' section dealt with the perception of the respondents regarding ten factors influencing the psychological contract. These were fairness, trust, the deal, transactional and relational elements, breach, violation, job satisfaction, organisational commitment, employee engagement and intentions to quit or stay. The 'Results' section presented three open-ended questions dealing with turnover intentions.

\section{Demographic information}

The participants of the study were mostly male employees and $80 \%$ were in the age group of 30-59 years of age. The average time of employment at the current position was 5 years, with $40 \%$ of the respondents being employed for less than 6 years and $12.4 \%$ for more than 20 years; $78 \%$ were permanently employed. The main qualification of the respondents was a doctorate degree followed by a master's degree. Very few respondents were in leadership positions with only $1 \%$ acting as deans or assistant deans. Heads of department accounted for $7.83 \%$ and section heads for $5.65 \%$. Only $26.52 \%$ of the respondents had been promoted within the organisation.

\section{Reliability analysis}

Cronbach's alpha was applied to measure the instrument's internal consistency. When the alpha is 0.70 or higher, it is considered acceptable in most social science research situations. The results for the subscales are presented in Table 2. From the table it is clear that the result for each is well above this accepted value, indicating that the study was reliable.

\section{Response to the survey items}

\section{Section 1: Psychological contract}

The responses to the items measuring fairness in the institute indicate many different perceptions. Of note is that $26.57 \%$ of
TABLE 2: Results from Cronbach's alpha.

\begin{tabular}{lc}
\hline Item description & Cronbach's alpha coefficient \\
\hline Fairness & 0.8229 \\
Trust & 0.8926 \\
The deal & 0.8808 \\
Transactional and relational elements & 0.7497 \\
Breach & 0.9303 \\
Violation & 0.9202 \\
Job satisfaction & 0.7866 \\
Organisational commitment & 0.8212 \\
Employee engagement & 0.6140 \\
Intentions to quit & 0.7900 \\
\hline
\end{tabular}

the respondents perceived some form of discrimination to be present. The responses to victimisation and bullying were equally positive and negative with a large percentage of uncertainty regarding the handling of sexual harassment incidents.

The issues dealt with in this section - victimisation, bullying, discrimination and sexual harassment - are not necessarily widely reported on in an organisation, as they are of a sensitive nature; therefore many employees might not be aware if they did actually occur, and if they did, how the organisation dealt with it.

The pattern of responses for the element of trust indicated that while most participants seemed to place a high level of trust in the employer to keep their promises, be honest and open and treat them fairly, a substantial percentage did not feel the same way. The percentages of agreeing with the statements was mostly in the vicinity of $50 \%$, with the exception of honesty and truthfulness, where only $35.75 \%$ agreed.

On measuring the perceptions of the deal, a number of specific items were presented. The participants' highest responses in specific categories were as follows:

- Training: $41.55 \%$ of participants believed that the organisation did well in keeping their training commitments.

- Rewards: $28.99 \%$ felt that the organisation rewarded good job performance poorly, and $14.49 \%$ felt that it rewarded it extremely poorly.

- Environment: $42.03 \%$ of participants believed that the organisation did well in providing a safe working environment and $26.57 \%$ believed it did marginally well.

- Job security: A significant $44.93 \%$ of participants believed that the organisation did well in providing job security.

- Promotion: $30.92 \%$ of participants believed that the organisation did well in providing a fair opportunity for promotion.

- Challenge: $38.16 \%$ of participants believed that the organisation did well, and $28.50 \%$ marginally well, in providing them with challenging work.

- Protean career: $31.88 \%$ of participants believed that the organisation did well, and $20.29 \%$ marginally poorly in skills development that they could use even if they left and joined another organisation. 
- Pay increase: $24.64 \%$ of participants believed that the organisation did poorly, and $26.57 \%$ extremely poorly, in providing salary increases based on performance.

- Human resource policies: $27.05 \%$ of participants believed that the organisation was fair and consistent in the application of Human Resources policies, processes and practices.

- Autonomy: 31.88\% of participants believed that the organisation enabled them to be autonomous in the various facets of their work.

- Recognition: $18.84 \%$ of participants believed that the organisation did poorly, and a significant 27.05\% extremely poorly, in recognising their contribution to the organisation.

The findings of this study suggest that both transactional and relational elements of the psychological contract were important to the participants. All elements, both relational and transactional in nature, elicited responses of $80 \%$ and higher. The highest responses recorded were for the elements of promotion at $92.27 \%$, support at $90.33 \%$, job security at $94.69 \%$, initiative at $90.34 \%$, abilities at $97.10 \%$ and work-life balance at $91.31 \%$. The most important top three elements were promotion, measuring $92.27 \%$ (transactional), job security at $94.69 \%$ (relational) and abilities at $97.10 \%$ (relational).

The opportunity to use their skills and abilities effectively $(97.10 \%)$ is the most important relational element to participants. The element 'being able to use your initiative' is somewhat related to abilities and also elicited a high response (90.34\%). It is clear that participants want to be given the opportunity to effectively use their skills, abilities and initiative. Job security $(94.69 \%)$ was the second most important relational element. Traditionally academic institutions are seen to provide job security that one does not necessarily find in the private sector. Promotion (92.27\%), the only transactional element, was considered the third most important element by participants.

\section{Section 2: Outcomes of fulfilment or breach}

The data collected indicated that positive psychological contracts appear to exist among participants. This is portrayed by the significant $50 \%$ of participants whose responses indicated that they did not perceive their contracts being breached. Those who did not share this positive view varied between a significant $30.92 \%$ and $37.68 \%$. The results regarding violation of the psychological contract were very much in line with these responses. It is necessary, however, to take note of the respondents who did not agree with the statement. Feelings of frustration, betrayal and anger were reported by $34.78 \%, 23.18 \%$ and $18.84 \%$, respectively.

The findings of this study showed that most employees were satisfied with their jobs; $85.51 \%$ of participants indicated that they were satisfied with their jobs while $89.86 \%$ disagreed with the statement that in general, they did not like their jobs. An overwhelming 90.82\% of participants indicated that they liked working at the organisation. Because the majority of the respondents were satisfied with their jobs, there is no surprise in the fact that the majority also indicated organisational commitment. Once again there was a substantial number who seemed to lack commitment.

The responses to the statements regarding levels of engagement suggested that most employees see themselves as constructively engaged at their workplaces, with high agreeable rates for knowing what is expected of them $(91.79 \%)$, having materials and equipment available $(76.81 \%)$, opportunities to exercise their natural abilities (78.26\%), having a positive relationship with supervisors $(74.88 \%)$, knowing the mission and purpose of their jobs (84.54\%) and feeling that their opinion counts (79.22\%). There were, however, a few notable exceptions:

- Recognition: The statement indicating that participants received recognition for good work in the last 7 days had the highest number of respondents disagreeing, at $65.70 \%$. This response indicated a disgruntled workforce who felt that their contributions were not being appreciated. Only $27.06 \%$ of respondents felt that their efforts were recognised.

- Quality: While 53.62\% agreed with the statement that fellow colleagues are committed to doing quality work, a large percentage $(31.40 \%)$ disagreed that there was a commitment to producing quality work. This is especially concerning for knowledge workers such as academics, as quality is an integral component of their work.

- Development: Almost half of the participants (46.37\%) disagreed that someone encouraged their development, while $48.31 \%$ agreed with the statement that someone encouraged their development.

- Progress: The statement regarding progress asked if the participants' progress were addressed by any one during the past 6 months. Alarmingly, 58.94\% of participants disagreed that their progress had been addressed in the past 6 months, while $33.82 \%$ agreed that this had taken place.

As for the intentions to quit, a large percentage of respondents indicated that they were not actively looking for alternative employment and that there was some gain in staying with the institute. Of concern, though, is the $35.75 \%$ of respondents who were often thinking about leaving and the $24.64 \%$ who were actively looking for alternative employment.

\section{Descriptive statistics}

By means of the Stata version 13 statistical software, the descriptive statistics for each set of variables were calculated. The mean, standard deviation, median, minimum and maximum values were produced for categorical variables. The median value was 4 for all the scales where the sevenpoint Likert scale was used. For the items of fairness, trust, breach, job satisfaction, organisation commitment and employee engagement the median was higher than the mean, indicating that the data were negatively skewed. The other 
four items, namely the deal, transactional or relational elements, violation of the contract and intentions to quit, had a median score lower than the mean, indicating that the data were positively skewed.

\section{Inferential statistics}

The chi-square test of association was performed in order to identify variables of significance. From the analysis it became clear that the ages of the participants had a significant influence on most statements, while leadership was much less significant, with only two $p$-values below 0.05 . These statements dealt with fair opportunity for promotion as well as the recognition of contributions. The results were that employees in non-leadership positions responded more positively to the statements. The relationship between the respondents' positions and the deal turned out to be highly significant, with 10 out of 14 statements resulting in a $p$-value below 0.05 . The results of the association between the position and organisational commitment delivered low indications of significance.

Further to the chi-square, the ANOVA test was also applied to identify significant relations between variables. The results indicated that tenure carried the most weight in influencing the participants' perceptions.

\section{Responses to the open-ended questions}

The last section of the questionnaire consisted of open-ended questions that requested participants to nominate the most important reasons that employees stay with their organisations, why employees leave and the actual practices implemented at the organisation to enhance employee retention.

The most frequently cited reasons for employees staying with the organisation were as follows:

- competitive and fair remuneration - $14 \%$

- recognition for contribution to the department, organisation and the profession $-10 \%$

- career development - personal and professional growth and development $-9 \%$

- job security $-9 \%$

The most frequently cited reasons for employees leaving an organisation were as follows:

- management: poor leadership, favouritism, conflict, low staff morale - $13 \%$

- unfair treatment $-12 \%$

- discrimination: based on culture and race $-11 \%$

- poor and unsafe work environment, perpetuated by student unrest $-9 \%$

- victimisation: particularly by managers $-8 \%$

- inconsistent or no promotion opportunities - 8\%

- heavy workload - 6\%

- recognition: no recognition for contributions to the department, faculty or organisation $-6 \%$
The most recommended retention practices were as follows:

- support: from managers and faculty in terms of growth and development of academics, including women - $11 \%$

- competitive remuneration and performance-based packages $-9 \%$

- promotion $-6 \%$

A significant $55 \%$ of participants indicated that the organisation did not have any retention practices in place to retain talented employees. Most of the recommended retention practices overlapped with the reasons why employees would leave the organisation, suggesting that management should consider implementing some of these recommendations from employees in order to retain them.

\section{Ethical considerations}

During the period of study, the essential ethical considerations were followed. Written approval was obtained from the ethics committee of Tshwane University of Technology for the study to be conducted at the university. The process included submission of the proposal, the questionnaire and the informed consent form for survey participants. Permission was also obtained to make use of an anonymous online data collection system, Question Pro, to collect data from a sample of randomly selected academic employees, in all six faculties at the institution.

\section{Discussion}

The main research question of this study was:

- What elements of the academic employee's psychological contract have impacted academic employee engagement at Tshwane University of Technology?

As the psychological contract fulfilment or breach has a direct influence on employee engagement, the study posted questions to determine the perceptions of the employees regarding these aspects. The findings indicated that the majority of the participants did not experience contract breach or violation. A significant percentage, however, felt that the organisation failed to keep promises made to them. According to Parzefall and Coyle-Shapiro (2011), there will be a decline in an employee's contribution to an organisation once the trust relationship has been damaged. It can therefore be concluded that a number of employees at the organisation might experience high turnover intentions. It was also recorded that feelings of frustration (34.78\%), betrayal (23.18\%) and anger (18.84\%) were experienced by some participants. Deery et al. (2006) as well as Flower et al. (2015) pointed out that these feelings could lead to organisational cynicism, which in turn leads to poor performance, low morale, high absenteeism, turnover, disillusionment, job dissatisfaction and fewer citizenship behaviours.

The majority of employees indicated that they were satisfied with their jobs, in general, liked their jobs and liked working 
at the organisation, indicating high levels of job satisfaction. This is in contrast to the literature by Shen (2010), who reported that serious contract violation may exist in the higher education sector, which will have a considerable negative effect on organisational performance. As most participants were experiencing job satisfaction, lower levels of turnover intentions were reported. The exception for this was for the middle-aged group, who reported lower levels of commitment with higher levels of turnover intentions.

The study found that both transactional and relational elements of the psychological contract were essential to academic employees. This is contrast to the findings of Shen (2010), who indicated that academic psychological contracts tend to be more transactional in nature. The findings suggested that a reasonably positive psychological contract existed among employees; however, a substantial number of employees perceived that they were being treated unfairly, did not trust the organisation and did not believe that the organisation would honour the deal. The employees were also unanimous in indicating that except for one retention practice, which they perceived as ineffective, the organisation had no retention practices or policies in place.

\section{Recommendations: Psychological contract breach and fulfilment}

Based on the findings of the study, the following recommendations are presented to the organisation.

Organisational agents must ensure that a realistic perception of the organisation is presented to prospective employees and be aware of promises made during this process. Policy or procedure changes must be communicated and explained clearly to manage possible breach. Efforts must be made to foster a trusting and quality relationship between employees, the organisation and its agents. The organisation must regularly assess the changes in employees' expectations of the organisation and what the organisation needs to contribute. Management should consider the factors contributing to intentions to quit when determining retention strategies for the organisation and ensure that they are integrated into policies and practices at the organisation. The organisation should invest in the employees and commit to making them feel valued and important. Included in this is encouragement and feedback on the employees' progress by managers and supervisors.

Some of the above can be achieved by effective management practices. The organisation must therefore ensure that managers possess the required management skills instead of using management jobs as promotional opportunities for career paths. Managers with the right talents are able to support, position, empower and engage their staff. They must be held accountable for their employees' engagement. Organisations should coach managers to take an active role in building engagement plans with their employees.

They should define engagement goals in everyday terms for employees and make them meaningful to employees' day-to-day experiences. Regular discussions and integration of engagement into daily interactions and activities enhance engagement. Managers should be aware of the factors most relevant to engagement among their employees and use every interaction with an employee as an opportunity to improve engagement levels and inspire discretionary effort.

The organisation should further offer inducements such as teamwork, pleasant working conditions, considerate treatment of employees, growth opportunities, skill enhancement and abundant training opportunities, creating the perception that there is a future with the organisation. Practices such as flexible working hours, which best support employees in balancing their work and home environments, should also be considered.

The most important factors that emerged from the transactional and relational elements were promotion, job security and the use of abilities and initiative. Management should consider these needs and ensure that they are able to fulfil them to the best of their ability.

\section{Recommendations: Retention practices}

The most recommended retention practices were as follows:

- support: from managers and faculty in terms of growth and development of academics, particularly women

- competitive remuneration and performance-based packages

- promotions

Management should consider urgently implementing a retention strategy that is relevant to employees in higher education, taking into consideration what academic employees value.

The organisation should assess why such a significant number of participants have intentions to leave the organisation, particularly those within the age group of 30 39. The organisation should strive to build a positive and strong organisational culture and assist new employees in adopting the culture of the organisation, which enhances commitment and satisfaction and improves retention.

\section{Implications for theory}

This study contributes the application of the psychological contract to engagement and retention management in a higher education context. Not many studies have been conducted in this field; therefore the study provides further insight into this phenomenon. The results of the study contribute to psychological contract literature. The study advances an understanding of academic employees' views of what they believe is important in terms of the psychological contract and employee retention and how this relates to behavioural and attitudinal outcomes such as engagement, organisational commitment and job satisfaction. 


\section{Implications for policy and practice}

The study brought into focus salient inducements such as competitive and fair remuneration, recognition of contributions, career development and job security that are specific to the psychology contracts of academic employees. When considering retention policies for the organisation, the organisation must include suggested inducements such as training for protean careers.

For organisations to be effective in managing the psychological contract, they must abandon commonly held views of what employees value. The study assisted in identifying what the respondents viewed as important, making a valuable contribution to the understanding of knowledge workers. In addition, employees should be part of the engagement process when determining organisational strategies regarding retention, employee engagement and job satisfaction. This will reduce the gap between promises made to employees and reality experienced and ensure greater levels of retention and engagement of talented employees, which is a critical factor for competitive advantage in organisations.

\section{Limitations and suggestions for future research}

The study focused on a single higher education institution and academic employees only. The results can therefore not be generalised to all institutions of higher education and the views of the support staff of the organisation.

Another important limitation is that the perceptions of organisational agents such as human resources managers, on whether employees were fulfilling their part of the psychological contract, were not explored. Further research including perceptions from both the organisation and employees is necessary to assess the impact of psychological contracts on employment relationships.

Another limitation faced is that in adopting a secondary data set as the basis for analysis, the questionnaire was limited with regard to certain aspects such as psychological contract breach and violation, as well as trust. The questionnaire also explores justice to a limited extent, the focus being on interactional rather than on distributive or procedural justice. Surveys, via questionnaires, are subject to bias, as they are instruments that are reported on by an individual. The impact of this bias nature could result in responses from the sample being over-reported or under-reported.

The following themes for further research emerged:

- A mixed methods research approach could be used with the existing sample, as well as support staff, expanding the scope of well-structured interviews to include not only employees but other parties such as organisational agents.

- The study was limited to a single higher education institution. Further studies could include other institutions of higher education in South Africa. This would provide a national perspective on psychological contracts in higher education institutions in South Africa.

\section{Contribution of the study}

There have been limited studies conducted on the relationship between psychological contracts and employee engagement. The results of this study add greatly to the body of academic knowledge on the psychological contract and employee engagement. The results of this study also add to the understanding of the nature of the academic psychological contract, which could assist higher education institutions in managing it. It also creates a better understanding of the needs of academic employees and the impact of psychological contract fulfilment and breach. This could benefit the higher education sector as a whole.

\section{Conclusion}

The purpose of this study was to assess whether the current state of academic employees' psychological contracts has impacted their levels of employee engagement. A review of the literature indicated a gap within the body of knowledge with respect to the academic psychological contract. The objective of the study was to investigate and attempt to answer the main research question: 'What elements of the academic employee's psychological contract have impacted on academic employee engagement at a university of technology?' The researchers believe that valuable findings and recommendations stem from this work.

\section{Acknowledgements Competing interests}

The authors declare that they have no financial or personal relationships that may have inappropriately influenced them in writing this article.

\section{Authors' contributions}

I.A. conducted the study and all data collection. R.R. was the first supervisor, guiding the student and overseeing the collection of the data and ethical conduct of the student. V.N. was the co-supervisor, ensuring the accuracy of data presentation.

\section{References}

Aggarwal, U. (2014). Linking justice, trust and innovative work behaviour to work engagement. Personnel Review, 43(1), 41-73. https://doi.org/10.1108/PR-02 2012-0019

Aggarwal, U., \& Bhargava, S. (2009). Reviewing the relationship between human resource practices and psychological contract and their impact on employee attitude and behaviours: A conceptual model. Journal of European Industria Training, 33(1), 4-31. https://doi.org/10.1108/03090590910924351

Allen, D. G., Bryant, P. C., \& Vardaman, J.M. (2010). Retaining talent: Replacing misconceptions with evidence-based strategies. The Academy of Management Perspectives, 24(2), 48-64.

Argyris, C. (1960). Understanding organizational behavior. Homewood: Dorsey Press.

Atkinson, C., \& Cuthbert, P. (2006). Does one size fit all? A study of the psychological contract in the UK working population. International Journal of Manpower, 27(7), 647-665. https://doi.org/10.1108/01437720610708266

Badat, S. (2010). The challenges of transformation in higher education and training institutions in South Africa. Johannesburg: Development Bank of Southern Africa, $1-56$. 
Bal, P. M., De Cooman, R., \& Mol, S. T. (2013). Dynamics of psychological contracts with work engagement and turnover intention: The influence of organizational with work engagement and turnover intention: The influence of organizational tenure. European Journal of Work and Organizationd

Bhattacharya, Y. (2015). Employee engagement as a predictor of seafarer retention: A study among Indian officers. The Asian Journal of Shipping and Logistics, 31(2), 295-318. https://doi.org/10.1016/j.ajsl.2015.06.007

Blancero, D. M., DelCampo, R. G., \& Marron, G. F. (2007). Perception of fairness in psychological contracts by Hispanic business professionals: An empirical study in United States. International Journal of Management, 24(2), 364-375.

Bruce, A., Zeynep, R., \& Yalabik, Y. (2014). Work engagement, psychological contract breach and job satisfaction. The International Journal of Human Resources Management, 25, 2382-2400. https://doi.org/10.1080/09585192. 2013.876440

Cassar, V. (2001). Violating psychological contract terms amongst Maltese public service employees: Occurrence and relationships. Journal of Manageria Psychology, 16(3), 194-208. https://doi.org/10.1108/02683940110385749

Chughtai, A. A., \& Buckley, F. (2013). Exploring the impact of trust on research scientists' work engagement: Evidence from Irish science research centres. Personnel Review, 42(4), 396-421. https://doi.org/10.1108/PR-06-2011-0097

Cohen, A. (2013). A global evaluation of organizational fairness and its relationship to psychological contracts. Career Development International, 18(6), 589-609. https://doi.org/10.1108/CDI-01-2013-0011

Conway, N., \& Briner, R. B. (2002). A daily diary study of affective responses to psychological contract breach and exceeded promises. Journal of Organisational Behaviour, 23, 287-302. https://doi.org/10.1002/job.139

Coyle-Shapiro, J. A. M. (2002). A psychological contract perspective on organizational citizenship behavior. Journal of Organizational Behavior, 23(8), 927-946. https:// doi.org/10.1002/job.173

Coyle-Shapiro, J. M., \& Parzefall, M. (2008). Psychological contracts. The SAGE Handbook of Organizational Behavior, 1, 17-34.

Davenport, T. H. (2005). Thinking for a living: How to get better performance and results from knowledge workers. Boston, MA: Harvard Business School Press.

Deery, S. J., Iverson, R. D., \& Walsh, J. T. (2006). 'Toward a better understanding of psychological contract breach: A study of customer service employees', Journa of Applied Psychology, 91(1), 169, 774-781. https://doi.org/10.1037/0021 9010.91.1.166

Devi, V. (2009). Employee engagement is a two-way street. Human Resources Management International Digest, 17(2), 3-4. https://doi.org/ 10.1108/09670730910940186

De Vos, A., \& Meganck, A. (2008). What HR managers do versus what employees value: Exploring both parties' views on retention management from a psychological contract perspective. Personnel Review, 38(1), 45-60. https://doi. org/10.1108/00483480910920705

Flower, R., Demir, D., McWilliams, J., \& Johnson, D. (2015). Perceptions of fairness in the psychological contracts of allied health professionals. Asia-Pacific Journal of Business Administration, 7(2), 106-116. https://doi.org/10.1108/ APJBA-03-2015-0022

Freese, C., \& Schalk, R. (1996). Implications of differences in psychological contracts for human resource management. Journal of Work and Organizational Psychology, 5(4), 501-509.

Gallup. (2013). Engagement at work: Its effect on performance continues in tough economic times. Retrieved from https://www.gallup.com/services/176657/ engagement-work-effect-performance-continues-tough-economic-times.aspx

George, C. (2015). Retaining professional workers: What makes them stay? Employee Relations, 37(1), 102-121. https://doi.org/10.1108/ER-10-2013-0151

Guest, D. E., \& Conway, N. (1998). Fairness and work and the psychological contract. London: Institute of Personnel and Development.

Gupta, B., Aggarwal, A., Samaria, P., Sarda, P., \& Bucha, R. (2012). Organisational commitment \& psychological contract in knowledge sharing behaviour. The Indian Journal of Industrial Relations, 47(4), 737-749.
Höglund, M. (2012). Quid pro quo? Examining talent management through the lens of psychological contracts. Personnel Review, 41(2), 126-142. https://doi. org/10.1108/00483481211199991

Hui, C., Lee, C., \& Rousseau, D. M. (2004). Psychological contract and organizational citizenship behavior in China: Investigating generalizability and instrumentality. Journal of Applied Psychology, 89(2), 311-321. https://doi.org/10.1037/0021 9010.89.2.311

Kahn, W. A. (1990). Psychological conditions of personal engagement and disengagement at work. Academy of Management Journal, 33(4), 692-724.

Kaye, B., \& Jordan-Evans, S. (2003). Love it, don't leave it: 26 ways to get what you want at work. Oakland, CA: Berrett-Koehler Publishers.

Luthans, F., \& Peterson, S. J. (2002). Employee engagement and manager selfefficacy: Implications for managerial effectiveness and development Journal of Management Development, 21(5), 376-387. https://doi. org/10.1108/02621710210426864

Martin, G., Staines, H., \& Pate, J. (1998). The new psychological contract: Exploring the relationship between job security and career development. Human Resource Management Journal, 6(3), 20-40.

Mayer, R. C., Davis, J. H., \& Schoorman, F. D. (1995). An integrative model of organizational trust. Academy of Management Review, 20(3), 709-734. https:// doi.org/10.5465/amr.1995.9508080335

Middlemiss, S. (2011). The psychological contract and implied contractual terms: Synchronous or asynchronous models? International Journal of Law and Management, 53(1), 32-50. https://doi.org/10.1108/17542431111111872

Neuman, W. L. (2006). Analysis of qualitative data. Social research methods: Qualitative and quantitative approaches. Boston, MA: Pearson.

Parzefall, M. R., \& Coyle-Shapiro, J. A. (2011). Making sense of psychological contract breach. Journal of Managerial Psychology, 26(1), 12-27. https://doi. org/10.1108/02683941111099592

Parzefall, M. R., \& Hakanen, J. (2010). Psychological contract and its motivational and health-enhancing properties, Journal of Managerial Psychology, 25(1), 4-21. https://doi.org/10.1108/02683941011013849

Pate, J., Martin, G., \& McGoldrick, J. (2003). The impact of psychological contract violation on employee attitudes and behaviour. Employee Relations, 25(6), 557-573. https://doi.org/10.1108/01425450310501306

Pitts, D., Marvel, J., \& Fernandez, S. (2011). So hard to say goodbye? Turnover intention among US federal employees. Public Administration Review, 71(5), 751-760. https://doi.org/10.1111/j.1540-6210.2011.02414.x

Punnett, B. J., \& Shenkar, O. (2004). Handbook for international management research. Ann Arbor, MI: University of Michigan Press.

Rayton, B. A., \& Yalabik, Z. Y. (2014). Work engagement, psychological contract breach and job satisfaction. The International Journal of Human Resource Management, 25, 2382-2400. https://doi.org/10.1080/09585192.2013.876440

Shen, J. (2010). University academics' psychological contracts and their fulfilment. Journal of Management Development, 29(6), 575-591. https://doi. org/10.1108/02621711011046549

Singh, R. (1998). Redefining psychological contracts with the US workforce: A critical task for strategic human resource management planners in the 1990's. Human Resource Management, 37(1), 61-69.

Sonnenberg, M., Koene, B., \& Paauwe, J. (2011). Balancing HRM: The psychological contract of employees: A multi-level study. Personnel Review, 40(6), 664-683. https://doi.org/10.1108/00483481111169625

Tomprou, M., \& Nikolaou, I. (2011). A model of psychological contract creation upon organizational entry. Career Development International, 16(4), 342-363. https:// doi.org/10.1108/13620431111158779

Winter, R., \& Jackson, B. (2006). State of psychological contract: Manager and employee perspective within an Australian credit union. Employee Relations, 5, 421-434. 